\title{
PENGARUH LINGKUNGAN KERJA DAN DISIPLIN KERJA TERHADAP KINERJA PEGAWAI DINAS PERINDUSTRIAN DAN PERDAGANGAN KABUPATEN INDRAGIRI HILIR
}

\author{
Bayu Sedih Nanda Ria \\ Sekolah Tinggi Ilmu Ekonomi ( STIE ) Dharma Putera, alamat..... \\ Email : bayu_snr@yahoo.com
}

\begin{abstract}
Creating employee performance in an organization is very important because it will directly or indirectly affect the work productivity of employees in an organization or agency. The purpose of this study was to determine the effect of work environment and work discipline on performance. The method in this research is descriptive quantitative with multiple linear regression. This study uses SPSS version 23,2019. This study used a saturated sampling technique or census method, then 46 respondents were selected, the sampling technique used was saturated sampling technique or census method and the data analysis used in the study was the multiple linear regression method with the result $Y=4,418+0.501 X 1+0.186 X 2+e$. The results of this study indicate that the independent variable, namely the work environment, has a positive and significant relationship to the dependent variable, namely the performance of the employees of the Indragiri downstream district industry and trade service. The $R 2$ in this study is 47.4 for the performance of the employees of the Indragiri Downstream Regency Industry and Trade Service. while the remaining $52.6 \%$ is explained by other variables not included in this study.
\end{abstract}

Keywords: work environment, work discipline and performance

\begin{abstract}
Abstrak
Menciptakan kinerja Aparatur Sipil Negara dalam organisasi publik adalah sangat penting karena secara langsung maupun tidak langsung akan mempengaruhi produktivitas kerja Aparatur Sipil Negara dalam suatu instansi. Tujuan penelitian ini adalah untuk mengetahui pengaruh lingkungan kerja dan disiplin kerja terhadap kinerja. Metode dalam penelitian ini adalah deskriptif kuantitatif dengan regresi linier berganda. Penelitian ini menggunakan SPSS versi 23,2019. Penelitian ini menggunakan teknik sampling jenuh atau metode sensus, maka terpilihlah 46 orang yang menjadi responden, teknik pengambilan sampel menggunakan teknik sampling jenuh atau metode sensus dan analisis data yang digunakan dalam penelitian adalah metode regresi linear berganda dengan hasil $\mathrm{Y}=4,418+0,501 \mathrm{X}_{1}+0,186 \mathrm{X}_{2}+\mathrm{e}$. Hasil penelitian ini menunjukkan bahwa variabel independen yaitu lingkungan kerja mempunyai hubungan yang positif dan signifikan terhadap variabel dependen yaitu kinerja pegawai dinas perindustrian dan perdagangan kabupaten Indragiri hilir.. $\mathrm{R}^{2}$ pada penelitian ini adalah sebesar 47,4 atas kinerja pegawai dinas perindustrian dan perdagangan kabupaten Indragiri hilir, sementara sisanya 52,6\% dijelaskan oleh variabel lain yang tidak dimasukkan dalam penelitian ini.
\end{abstract}

\section{Kata Kunci : Lingkungan kerja, Disiplin Kerja dan Kinerja}




\section{PENDAHULUAN}

Tujuan dari Fungsi manajemen sumber daya manusia adalah agar perusahaan mendapatkan rentabilitas laba yang lebih besar. Karyawan bertujuan mendapatkan kepuasan dari pekerjaannya. Masyarakat bertujuan memperoleh barang atau jasa yang baik dengan harga wajar. Seorang karyawan dapat 2 dikatakan mengerjakan tugas yang baik apabila ia mengerjakan tugas yang sesuai dengan fungsi-fungsinya.

Kinerja pegawai dipengaruhi oleh berbagai faktor, antara lain: lingkungan kerja, disiplin kerja, budaya organisasi, kepemimpinan, dan motivasi kerja.Pada penelitian ini akan dibahas mengenai lingkungan kerja dan disiplin kerja serta hubungannya dengan kinerja pegawai. Kinerja yang baik adalah kinerja yang sesuai dengan standar organisasi yang mendukung tercapainya tujuan organisasi. Organisasi yang baik adalah organisasi yang berusaha meningkatkan kemampuan sumber daya manusianya, karena hal tersebut merupakan kunci untuk meningkatkan kinerja pegawai.

Adapun fenomena yg terjadi dari aspek kinerja di dinas tersebut ialah dimana kinerja pegawai tidak sesuai dengan target yang telah ditentukan oleh pimpinan, dan juga adanya komplen dari masyarakat karena pegawai terlalu lama mengeluarkan surat perizinan seperti surat izin buka usaha dagang dan lain lain.

Tabel 1.1: Rekapitulasi Penilaian Kinerja Pegawai Dinas Perindustrian dan Perdagangan Kab Inhil Tahun 2016-2019

\begin{tabular}{|c|c|c|c|c|c|}
\hline \multirow[b]{2}{*}{ No } & \multirow[b]{2}{*}{ Tahun } & \multicolumn{2}{|c|}{ Unsur Yang Dinilai } & \multirow{2}{*}{$\begin{array}{c}\text { Nilai } \\
\text { Prestasi } \\
\text { Kerja(\%) }\end{array}$} & \multirow[b]{2}{*}{ Kategori } \\
\hline & & $\begin{array}{c}\text { Sasaran Kerja } \\
\text { Pegawai(SKP)(\%) }\end{array}$ & $\begin{array}{l}\text { Perilaku } \\
\text { Kerja(\%) }\end{array}$ & & \\
\hline 1 & 2016 & 49,20 & 32,81 & 82,01 & Baik \\
\hline 2 & 2017 & 49,35 & 31,90 & 81,25 & Baik \\
\hline 3 & 2018 & 50,11 & 30,98 & 81,09 & Baik \\
\hline 4 & 2019 & 50,01 & 31,85 & 81,86 & Baik \\
\hline
\end{tabular}

Sumber : Dinas Perindustrian dan Perdagangan Kab Inhil, 2020

Dari Tabel di 1.1 dapat dilihat bahwa pada tahun 2016 kinerja Disperindag memperoleh nilai 82,01 kategori baik pada tahun 2017 memperoleh nilai 81,25 dan tahun 2018 memperoleh nilai kinerja 81,09 dan pada tahun 2019 kategori penilaian adalah baik yaitu kenaikan kinerja dengan nilai 81,86 . Dapat dilihat dari data di atas 
kinerja pada pegawai Disperindag mengalami penurunan dari tahun 2016-2018 dan mengalami peningkatan pada tahun 2019.

Lingkungan kerja ini meliputi tempat bekerja, fasilitas dana alat bantu pekerjaan, kebersihan, pencahayaan, ketenangan termasuk juga hubungan kerja antara orang-orang yang ada di tempat. Lingkungan kerja yang baik dapat membantu pegawai bekerja dengan tenang dan tidak membuat mereka cepat jenuh dalam bekerja, sehingga akan merasa puas dengan hasil kerjanya.

Dengan adanya fasilitas-fasilitas yang diberikan instansi, maka hal ini sangat berpengaruh langsung terhadap kinerja pegawai sehingga akan memberikan implikasi yang baik pula bagi perusahaan. Lingkungan Kerja Non Fisik juga berpengaruh terhadap Kinerja Pegawai, lingkungan yang bersifat batiniah seperti hubungan pertemanan atau hubungan sosial antara anggota organisasi. Instansi hendaknya mencerminkan kondisi kerja yang mendukung kerja satu sama lain, kondisi yang diciptakan hendaknya bersifat kekeluargaan, komunikasi yang baik dan pengendalian diri.

Disiplin kerja merupakan sikap sadar atau kesediaan seorang pegawai untuk melakukan dan mentaati aturan-aturan yang ditetapkan oleh perusahaan. Pegawai dengan disiplin kerja yang baik diharapkan mampu melaksanakan dan menyelesaikan pekerjaan yang menjadi tanggung jawabnya dengan efektif dan efisien serta tepat pada waktunya. Ketaatan dalam melaksanakan aturan yang ditentukan oleh organisasi dalam bekerja, dengan maksud agar tenaga kerja

Disperindag melihat adanya pegawai yang hanya datang di waktu pagi saja dan tidak masuk lagi saat jam kerja siang, pegawai yang terlambat, pegawai yang tidak masuk kerja tanpa keterangan, bahkan masih ada pegawai yang meninggalkan kantor tanpa alasan yang jelas, Berdasarkan uraian diatas tergambar dalam tabel sebagai berikut : 
Tabel 1.2 : Rekapitulasi Pelanggaran Absensi Pegawai Dinas Perindustrian dan Perdagangan Kabupaten Indragiri Hilir 2015-2019

\begin{tabular}{|l|c|c|c|}
\hline \multirow{2}{*}{ Tahun } & \multirow{2}{*}{$\begin{array}{l}\text { Pumlah } \\
\end{array}$} & Rata $^{2}$ Alpa/Tahun & Rata $^{2}$ Lambat Masuk/Tahun \\
\cline { 3 - 4 } & 39 & Frekuensi & Frekuensi \\
\hline 2015 & 39 & 11 orang & 9 orang \\
\hline 2016 & 41 & 9 orang & 9 orang \\
\hline 2017 & 44 & 7 orang & 12 orang \\
\hline 2018 & 46 & 8 orang & 11 orang \\
\hline 2019 & 11 orang & 13 orang \\
\hline
\end{tabular}

Sumber : Dinas Perindustrian dan Perdagangan Kab Inhil, 2020

Tabel di atas menggambarkan pada tahun 2015 pelanggaran absensi dengan jumlah pegawai 39 orang dengan frekuensi alpa rata rata alpa 11 orang dan terlambat 9 orang. Pada tahun 2016 jumlah pegawai 39 orang dengan frekuensi alpa 9 orang dan terlambat 9 orang. Pada tahun 2017 jumlah pegawai 41orang dengan frekuensi alpa 7 orang dan terlambat 12 orang. Pada tahun 2018 jumlah pegawai 44 orang dengan frekuensi alpa 88 orang dan terlambat 11 orang. Pada tahun 2019 jumlah pegawai 46 orang dengan frekuensi alpa 11 orang dan terlambat 13 orang dapat disimpulkan bahwa disiplin pegawai dinas perindustrian dan perdagangan kab inhil rendah.

Tabel 1.3 : Rekapitulasi Absensi Pegawai Sakit, Izin, Alpa (Tanpa Keterangan), dan Terlambat Dinas Perindustrian dan Perdagangan Kabupaten Indragiri Hilir Tahun 2015-2019

\begin{tabular}{|c|c|c|c|c|c|}
\hline \multirow{2}{*}{ Tahun } & \multirow{2}{*}{$\begin{array}{c}\text { Kumlah Hari } \\
\text { Kerja/Tahun }\end{array}$} & Sakit(\%) & Izin(\%) & $\begin{array}{c}\text { Alpa/Tanpa } \\
\text { Keterangan(\%) }\end{array}$ & $\begin{array}{c}\text { Terlambat } \\
(\%)\end{array}$ \\
\hline 2015 & 228 Hari & $7(3 \%)$ & $3(1,3 \%)$ & $11(4,8 \%)$ & $9(3,9 \%)$ \\
\hline 2016 & 225 Hari & $6(2,6 \%)$ & $4(1,7 \%)$ & $9(4 \%)$ & $9(3,9 \%)$ \\
\hline 2017 & 226 Hari & $5(2,2 \%)$ & $3(1,3 \%)$ & $7(3 \%)$ & $12(5,3 \%)$ \\
\hline 2018 & 226 Hari & $5(2,2 \%)$ & $5(2,2 \%)$ & $8(3,5 \%)$ & $11(4,8 \%)$ \\
\hline 2019 & 225 Hari & $6(2,6 \%)$ & $4(1,7 \%)$ & $11(4,8 \%)$ & $13(5,7 \%)$ \\
\hline
\end{tabular}

Sumber : Dinas Perindustrian dan Perdagangan Kab Inhil, 2020 
Tabel 1.3 diatas menunjukan pada tahun 2015 jumlah hari kerja pertahun 228 hari dengan Absensi Sakit sebanyak 3\% pertahunnya dan izin sebanyak 1,3\% pertahun dan alpa sebanyak 4,8\% pertahun dan terlambat sebanyak 3,9\% pertahun. Pada tahun 2016 jumlah hari kerja pertahun 225 hari dengan Absensi Sakit sebanyak $2,6 \%$ pertahunnya dan izin sebanyak $1,7 \%$ pertahun dan alpa sebanyak $4 \%$ pertahun dan terlambat sebanyak 3,9\% pertahun. Pada tahun 2017 jumlah hari kerja pertahun 226 hari dengan Absensi Sakit sebanyak 2,2\% pertahunnya dan izin sebanyak 1,3\% pertahun dan alpa sebanyak $43 \%$ pertahun dan terlambat sebanyak 5,3\% pertahun. Pada tahun 2018 jumlah hari kerja pertahun 226 hari dengan Absensi Sakit sebanyak $2,2 \%$ pertahunnya dan izin sebanyak $2,2 \%$ pertahun dan alpa sebanyak $3,5 \%$ pertahun dan terlambat sebanyak 4,8\% pertahun. Pada tahun 2019 jumlah hari kerja pertahun 225 hari dengan Absensi Sakit sebanyak 2,6\% pertahunnya dan izin sebanyak 1,7\% pertahun dan alpa sebanyak 4,8\% pertahun dan terlambat sebanyak 5,7\% pertahun.

\section{TELAAH LITERATUR DAN PENGEMBANGAN HIPOTESIS}

\subsection{Manajemen Sumber Daya Manusia}

Manajemen sumber daya manusia dapat dikatakan juga sebagai manajemen dalam perusahaan karena itu, teori-teori manajemen umum menjadi dasar pembahasannya.

Menurut Hasibuan (2012:10) Manajemen sumber daya manusia lebih memfokuskan pembahasannya mengenai peraturan peranan manusia, dalam mewujudkan tujuan yang optimal pengaturan itu meliputi masalah perencanaan (human resources planing), pengorganisasian, pengarahan, pengendalian, pengadaan, pengembangan, kompensasi, pengintegrasian, pemeliharaan, kedisiplinan, dan pemberhentian tenaga kerja untuk membantu terwujudnya tujuan perusahaan, pegawai dan masyarakat.

Hasibuan (2009 : 28) Manajemen personalia adalah penyedia kepemimpinan dan pengarahan para pegawai dalam pekerjaan atau hubungan kerja antar mereka. Jadi, manajemen sumber manusia adalah ilmu dan seni untuk mengatur tenaga manusia agar efektif dan efisien dalam mewujudkan tujuan organisasi, kepuasan karyawan dan masyarakat. 
Tantangan para pimpinan adalah bagaimana mengelola SDM dengan efektif dan menghilangkan hal-hal yang tidak efektif. Sedangkan kondisi lingkungan dituntut untuk selalu mengembangkan cara-cara baru untuk dapat menarik dan mempertahankan para pegawai. Tujuan utama manajemen sumber daya manusia adalah untuk meningkatkan kontribusi pegawai terhadap organisasi dalam rangka mencapai produktifitas organisasi yang bersangkutan.

\subsection{Pengertian Kinerja}

Istilah kinerja berasal dari kata jobperformance dan actual performance (prestasi kerja atau prestasi sesungguhnya yang dicapai oleh seseorang). Menurut Mangkunegara (2012:67) istilah kinerja berasal dari kata Job Performance atau Actual Performance (prestasi kerja atau prestasi sesungguhnya yang dicapai oleh seseorang). Pengertian kinerja adalah hasil kerja secara kualitas dan kuantitas yang dicapai oleh seorang karyawandalam melaksanakan tugasnya sesuai dengan tanggung jawab yang diberikan kepadanya. Kinerja pegawai sering di artikan sebagai pencapaian tugas, dimana pegawai dalam bekerja harus sesuai dengan program kerja organisasi untuk menunjukan tingkat kinerja organisasi dalam mencapai visi, misi, tujuan organisasi.

Jadi dari pendapat para ahli diatas maka penulis membuat pengertian yang sederhana mengenai kinerja adalah kemampuan seorang pegawai atau pegawai dalam menyelesaikan tugas atau tanggung jawabnya yang menghasilkan suatu tingkat keberhasilan seseorang secara keseluruhan selama periode tertentu dengan berbagai kemungkinan seperti standar hasil kerja, target dan kriteria yang sudah di tentukan.

\subsubsection{Faktor-Faktor Yang Mempengaruhi Kinerja}

Menurut Gibson dalam Mangkunegara (2008:68) ada 3 faktor yang berpengaruh terhadap kinerja:

1. Faktor individu: kemampuan, keterampilan, latar belakang keluarga, pengalaman kerja, tingkat sosial dan demografi seseorang

2. Faktor psikologis: persepsi, peran, sikap, kepribadian, motivasi dan kepuasan kerja

3. Faktor organisasi : struktur organisasi, desain pekerjaan, kepemimpinan, sistem penghargaan (rewardsystem) 
Kinerja pegawai berkurang apabila salah satu faktor ini berkurang atau tidak ada. Sebagai contoh beberapa pegawai memiliki kemampuan untuk melakukan pekerjaannya dan bekerja keras, tetapi organisasi memberikan peralatan yang kuno. Masalah kinerja merupakan hasil kerja yang dicapai seseorang dalam melaksanakan tugas dan tanggung jawab yang dibebankan kepada pegawai. kinerja meliputi kualitas output serta kesadaran dalam bekerja.

\subsubsection{Indikator Kinerja}

Menurut Russel dalam Samsuddin (2018:75) untuk mengukur kinerja pegawai dapat digunakan beberapa criteria kinerja anatara lain adalah :

1. Kualitas (Quality) merupakan tingkatan di mana proses atau hasil dari penyelesaian suatu kegiatan mendekati sempurna.

2. Kuantitas (Quantity) merupakan produksi yang dihasilkan dapat ditunjukan dalam satuan mata uang, jumlah unit, atau jumlah siklus kegiatan yang diselesaikan.

3. Ketepatan waktu (Timeliness) merupakan di mana kegiatan tersebut dapat diselesaikan, atau suatu hasil produksi dapat dicapai, pada permulaan waktu yang ditetapkan bersamaan koordinasi dengan hasil produk yang lain dan memaksimalkan waktu yang tersedia untuk kegiatan-kegiatan lai

\subsection{Lingkungan Kerja}

Menurut Sedarmayanti (2011:21) lingkungan kerja adalah keseluruhan alat perkakas dan bahan yang dihadapi, lingkungan sekitarnya dimana seseorang bekerja, metode kerjanya, serta pengaturan kerjanya baik sebagai perseorangan maupun kelompok. Menurut Nitisemito (2010:183) Lingkungan kerja adalah segala sesuatu yang ada di lingkungan sekitar para pekerja dan yang dapat mempengaruhi dirinya dalam menjalankan tugas-tugas yang dibebankan kepadanya, misalnya kebersihan,musik,dan lain-lain. Menurut Sukoco (2009:214) "Lingkungan kantor sedikit banyak akan 
mempengaruhi fisik maupun psikologis pegawai ketika melakukan pekerjaan. Oleh karena itu sangat penting bagi Manajerial Adminstrasi untuk menciptakan lingkungan kerja yang bisa membuat pegawainya bekerja secara efektif dan efisien.

Lingkungan kerja merupakan salah satu faktor penting dalam menciptakan kinerja pegawai. Karena lingkungan kerja mempunyai pengaruh langsung terhadap pegawai dalam menyelesaikan pekerjaan yang pada akhirnya akan meningkatkan kinerja organisasiFaktor-Faktor yang mempengaruhi lingkungan kerja

Berikut ini beberapa faktor yang diuraikan oleh Sedarmayanti (2009:21) yang dapat mempengaruhi terbentuknya suatu kondisi lingkungan kerja dikaitkan dengan kemampuan pegawai, yaitu:

1. Warna

Warna merupakan faktor yang penting untuk memperbesar efesiensi kerja para pegawai. Khususnya warna akan mempengaruhi keadaan jiwa mereka. Dengan memakai warna yang tepat pada dinding ruangan dan alat-alat lainnya, kegembiraan dan ketenangan bekerja para pegawai akan terpelihara.

2. Kebersihan

Kebersihan lingkungan kerja tidak langsung dapat mempengaruhi seseorang dalam bekerja, karena apabila lingkungan kerja bersih maka karyawan akan merasa nyaman dalam melakukan pekerjaannya. Kebersihan lingkungan bukan hanya berarti kebersihan tempat mereka bekerja, tetapi jauh lebih luas dari pada itu misalnya toilet yang berbau tidak enak akan menimbulkan rasa yang kurang menyenang kan bagi para pegawai yang menggunakannya, untuk menjaga kebersihan ini pada umumnya diperlukan petugas khusus, dimana masalah biaya juga harus di pertimbangkan

\section{Penerangan atau cahaya}

Penerangan dalam hal ini bukan terbatas pada penerangan listrik saja, tetapi juga penerangan sinar matahari. Dalam melaksanakan tugas 
pegawai membutuhkan penerangan yang cukup, apabila pekerjaan yang dilakukan tersebut menuntutu ketelitian.

\subsubsection{Jenis-Jenis Lingkungan Kerja}

Menurut Sedarmayanti (2011:26) secara garis besar, jenis lingkungan kerja terbagi menjadi 2 yakni : 1) lingkungan kerja fisik, dan 2) lingkungan kerja non fisik :

1. Lingkungan kerja fisik.

Lingkungan kerja fisik adalah semua keadaan yang berbentuk fisik yang terdapat disekitar tempat kerja yang dapat mempengaruhi pegawai baik secara langsung, seperti : pusat kerja, kursi, meja, dan lain lain

2. Lingkungan kerja non fisik

Sedarmayanti (2011:26) menyatakan bahwa lingkungan kerja non fisik adalah semua keadaan yang terjadi dan berkaitan dengan hubungan kerja, baik dengan pimpinan maupun dengan sesame rekan kerja ataupun hubungan dengan bawahan, Lingkungan kerja non fisik ini merupakan lingkungan kerja yang tidak bisa diabaikan.

\subsection{Pengertian Disiplin Kerja}

Menurut Sutrisno (2009:86) mengatakan disiplin adalah sikap kesediaan dan kerelaan seseorang untuk mematuhi dan menaati norma-norma peraturan yang berlaku disekitarnya. Disiplin yang baik akan mempercepat tujuan perusahaan, sedangkan disiplin yang merosot akan menjadi penghalang dan penghambat tujuan instansi.

Menurut Rivai (2010:825) disiplin kerja adalah suatu alat yang digunakan para pimpinan untuk berkomunikasi dengan pegawai agar mereka bersedia untuk mengubah suatu perilaku serta sebagai suatu upaya meningkatkan kesadaran dan kesediaan seseorang menaati semua peraturan perusahaan dan norma-norma sosial yang berlaku. 


\subsubsection{Faktor-Faktor Yang Mempengaruhi Disiplin Kerja}

Disiplin merupakan bentuk pengendalian diri pegawai dan pelaksanaan yang teratur dan menunjukkan tingkat kesungguhan pegawai didalam organisasi. Tidak disiplin menuntut suatu hukuman terhadap pegawai yang gagal memenuhi standar yang ditetapkan.

Hasibuan (2009:194) Faktor yang mempengaruhi disiplin kerja pegawai adalah sebagai berikut :

a. Tujuan dan kemampuan

Tujuan dan kemampuan ikut mempengaruhi tingkat kedisiplinan pegawai, tentu saja pada dasarnya pekerjaan yang di bebankan keryawan harus sesuai dengan kemampuan pegawai tersebut agar pegawai tersebut disiplin dan bersungguh-sungguh dalam melakukan tugas tersebut.

b. Kepemimpinan sangat memiliki peranan penting dalam menentukan kedisiplinan kerja pegawai karena pemimpin tersebut akan menjadi contoh sebagai para bawahannya.

c. Kompensasi

Kompensasi sangat berperan penting terhadap kedisiplinan kerja pegawai, artinya semakin besar kompensasi yang di berikan perusahaan, semakin baik disiplin kerja pegawai. Begitu juga sebaliknya pegawai akan sulit bekerja dengan disiplin jik primer meraka tidak terpenuhi. 


\section{$2.5 \quad$ Kerangka pemikiran}

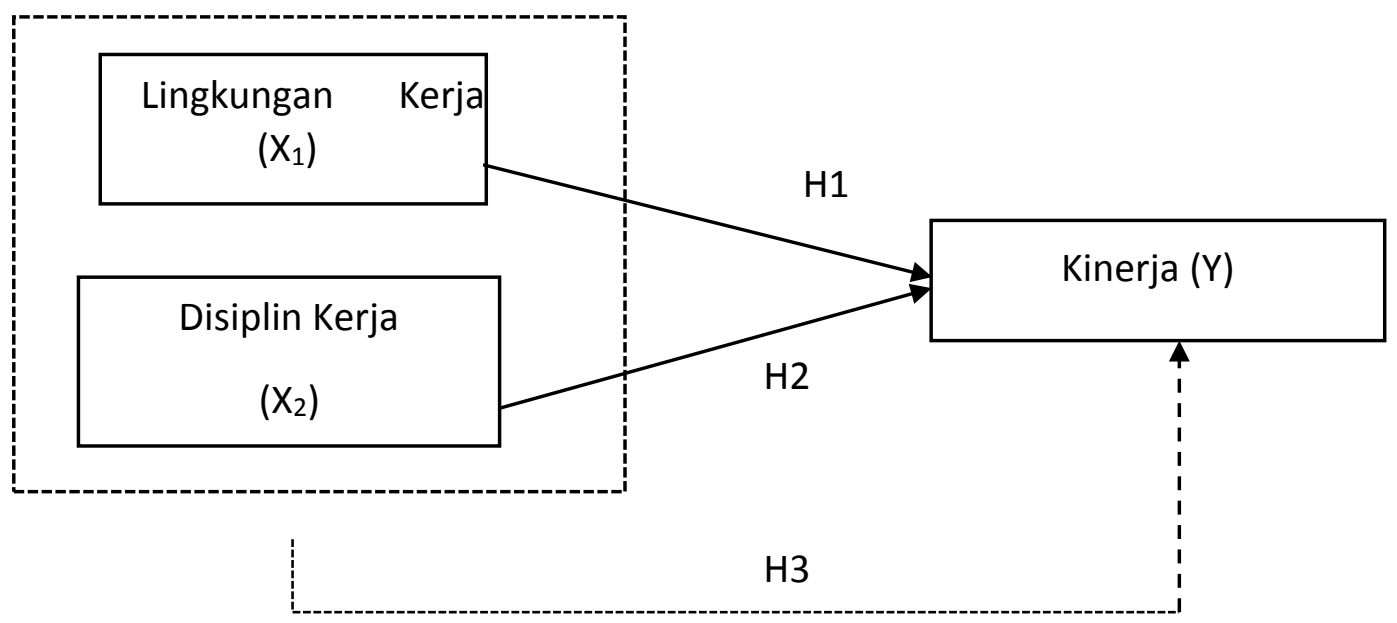

\subsection{Hipotesis Penelitian}

Jadi berdasarkan masalah yang di kemukakan diatas dan kemudian dengan memperhatikan teori-teori yang ada, maka penulis dapat mengemukakan hipotesis sebagai dugaan sementara penelitian sebagai berikut:

H1: Diduga lingkungan kerja berpengaruh secara parsial terhadap Kinerja Pegawai Disperindag Kecamatan Tembilahan Kabupaten Indragiri Hilir

H2: Diduga disiplin Kerja berpengaruh secara parsial terhadap Kinerja Disperindag Kecamatan Tembilahan Kabupaten Indragiri Hilir

H3: Diduga lingkungan kerja dan disiplin kerja berpengaruh secara simultan terhadap Kinerja Disperindag Kec Tembilahan Kab Indragiri Hilir

\section{METODE PENELITIAN}

\subsection{Lokasi Penelitian}

Penelitian ini dilakukan di Dinas Perindustrian dan Perdagangan

Kabupaten Indragiri Hilir 


\subsection{Populasi dan Sampel Penelitian}

Menurut Purwanto (2011:7) Populasi adalah Kumpulan dari semua kemungkinan orang-orang, benda-benda dan ukuran lain, yang menjadi perhatian. Populasi dari penelitian ini adalah seluruh pegawai di Disperindag Kabupaten Indragiri Hilir yaitu sebanyak 46 orang.

Menurut Purwanto (2011:7) Sampel adalah bagian dari populasi tertentu yang menjadi perhatian. Untuk menentukan jumlah sampel yang di ambil pada penelitian ini adalah keseluruhan dari jumlah populasi yaitu pegawai Disperindag Kabupaten Indragiri Hilir sebanyak 46 orang. Metode dalam penentuan sampel tersebut adalah metode sensus.

\subsection{Teknik Pengumpulan Data}

Kuesioner

Menurut Sugiyono (2009:199) yaitu teknik pengumpulan data yang dilakukan dengan cara memberi seperangkat pernyataan atau pertanyaan tertulis kepada responden untuk dijawabnya. Kuisioner yang di berikan dan aliran di beri nilai (Skor)

\subsection{Teknik Analisis Data}

Jenis data yang digunakan dalam penelitian ini adalah data Kuantitatif, yaitu data yang diukur dalam suatu skala numerik (angka). Data dalam laporan penelitian ini bersifat kuantitatif karena data diperoleh dengan mengukur nilai beberapa variabel dalam sampel atau populasi. Data kuantitatif yaitu data atau keterangan yang berupa angka-angka tabel atau bagan. Untuk mengukur hubungan masing-masing variabel dibantu komputerisasi melalui program SPSS (Statictical Package for Social Science) versi 23. 


\section{HASIL DAN PEMBAHASAN}

\subsection{Uji Reabilitas}

\begin{tabular}{|l|l|l|l|l|}
\multicolumn{1}{|c}{ Tabel 4.1 : Hasil Uji Reliabilitas } \\
\hline & $\begin{array}{l}\text { Cronbach's } \\
\text { Alpha }\end{array}$ & Tanda & Nilai & Kesimpulan \\
\hline Lingkungan Kerja (X1) & 0,644 & $>$ & 0,60 & Reliabel \\
\hline Disiplin Kerja (X2) & 0,760 & $>$ & 0,60 & Reliabel \\
\hline Kinerja (Y) & 0,680 & $>$ & 0,60 & Reliabel \\
\hline
\end{tabular}

Sumber :Data olahan SPSS 232019

Berdasarkan tabel 4.1 hasil pengujian alat ukur yang digunakan dalam penelitian ini, nilai cronbach's alpha yang dihasilkan dengan pengolahan menggunakan bantuan SPSS 23 berada diatas 0,60 maka alat ukur instrument yang digunakan dalam penelitian ini dianggap reliabel atau konsisten bila digunakan dalam beberapa kali pengukuran.

\subsection{Uji Multikoliniaritas}

Tabel 4.2 Uji Multikolinieritas

\section{Coefficients $^{\text {a }}$}

\begin{tabular}{|ll|l|l|}
\hline \multirow{2}{*}{ Model } & \multicolumn{2}{|l|}{ Collinearity Statistics } \\
\cline { 3 - 4 } & & Tolerance & VIF \\
\hline 1 & (Constant) & & \\
& Lingkungan Kerja & .857 & 1.166 \\
& Disiplin Kerja & .857 & 1.166 \\
\hline
\end{tabular}

Berdasarkan tabel 4.2 hasil penolahan data dalam penelitian ini denan menggunakan bantuan SPSS 23 terlihat nilai VIF (Variance Inflation Factor) yang dihasilkan dalam pengujian ini variabel Lingkungan Kerja sebesar 1.166, Disiplin Kerja sebesar 1,166. Dengan melihat nilai VIF (Variance Inflation Factor) yang dihasilkan oleh masing-masing variabel lebih kecil dari 10, maka dapat disimpulkan pada model regresi yang terbentuk dalam penelitian ini tidak terjadi gejala multikolinieritas. 


\subsection{Uji Autokorelasi}

\subsection{Tabel 4.3 Hasil Uji Autokorelasi}

Model Summary ${ }^{b}$

\begin{tabular}{|l|l|l|l|l|l|}
\hline Model & $\mathrm{R}$ & $\mathrm{R}$ Square & $\begin{array}{l}\text { Adjusted Rquare } \\
\text { Square }\end{array}$ & $\begin{array}{l}\text { Std. Error of } \\
\text { the Estimate }\end{array}$ & $\begin{array}{l}\text { Durbin- } \\
\text { Watson }\end{array}$ \\
\hline 1 & $.689^{\mathrm{a}}$ & .474 & .450 & 1.31961 & 1.967 \\
\hline
\end{tabular}

a. Predictors: (Constant), Disiplin Kerja, Lingkungan Kerja

b. Dependent Variable: Kinerja

Berdasarkan tabel 4.3 rekapitulasi uji autokorelasi, diperoleh nilai Durbin Watson sebesar 1,967. Apabila dilihat dari tabel Durbin-Watson dengan $\mathrm{n}=46$, dan $\mathrm{K}=2$, maka diperoleh nilai $\mathrm{dL}=1,436$ dan $\mathrm{dU}=1,617$, sehingga nilai 4-dU sebesar 2,383 sedangkan nilai 4-dL sebesar 2,564. Maka dapat dilihat dari kriteria di atas, karena nilai dL $(1,436)$ lebih kecil sama dengan Dw $(1,967)$ lebih kecil sama dengan 4-dU $(2,383)$, maka dapat disimpulkan bahwa tidak terdapat autokorelasi pada uji autokorelasi diatas.

\subsection{Uji Regresi Linier Berganda}

Coefficients $^{\mathrm{a}}$

\begin{tabular}{|c|c|c|c|c|c|c|}
\hline \multirow{2}{*}{\multicolumn{2}{|c|}{ Model }} & \multicolumn{2}{|c|}{$\begin{array}{c}\text { Unstandardized } \\
\text { Coefficients }\end{array}$} & \multirow{2}{*}{$\begin{array}{c}\begin{array}{c}\text { Standardized } \\
\text { Coefficients }\end{array} \\
\text { Beta }\end{array}$} & \multirow[b]{2}{*}{$\mathrm{T}$} & \multirow[b]{2}{*}{ Sig. } \\
\hline & & B & $\begin{array}{l}\text { Std. } \\
\text { Error }\end{array}$ & & & \\
\hline \multirow[t]{3}{*}{1} & (Constant) & 4.418 & 2.615 & & 1.689 & .098 \\
\hline & Lingkungan Kerja & .501 & .107 & .559 & 4.682 & .000 \\
\hline & Disiplin Kerja & .186 & .092 & .243 & 2.035 & .048 \\
\hline
\end{tabular}

a. Dependent Variable: Kinerja

Berdasarkan tabel 4.4 maka dapat diketahui sebagai berikut:

1. Variabel Lingkungan Kerja, diketahui thitung 4,682> t tabel 2,016 dan sig $(0,000)<0,05$. Artinya secara parsial variabel Lingkungan Kerja berpengaruh terhadap Kinerja.

2. Variabel Disiplin Kerja, diketahui t hitung 2,035>t tabel 2,016 dan sig $(0,048)<0,05$. Artinya secara parsial variabel Disiplin Kerja berpengaruh terhadap Kinerja. 
Tabel 4. 5 Uji Secara Simultan (Uji F)

ANOVA $^{\mathrm{a}}$

\begin{tabular}{|c|c|c|c|c|c|c|}
\hline \multicolumn{2}{|c|}{ Model } & $\begin{array}{l}\text { Sum of } \\
\text { Squares }\end{array}$ & Df & $\begin{array}{l}\text { Mean } \\
\text { Square }\end{array}$ & $\mathrm{F}$ & Sig. \\
\hline \multirow[t]{3}{*}{1} & Regression & 67.555 & 2 & 33.778 & 19.397 & $.000^{\mathrm{b}}$ \\
\hline & Residual & 74.879 & 43 & 1.741 & & \\
\hline & Total & 142.435 & 45 & & & \\
\hline
\end{tabular}

a. Dependent Variable: Kinerja (Y)

b. Predictors: (Constant), Disiplin Kerja (X2), Lingkungan Kerja (X

Dari tabel 5.14 diatas diketahui bahwa Fhitung sebesar $(19,397)$ dengan signifikan 0,000 dan jumlah Ftabel statistik sebesar 3,21. Dengan demikian diketahui Fhitung sebesar $(19,397)>$ Ftabel $(3,21)$ dengan signifikansi $0,000<0,05$. Artinya bahwa variabel independen (Lingkungan Kerja dan Disiplin Kerja) secara bersama-sama berpengaruh dan signifikan terhadap variabel dependen (Kinerja).

\subsection{Koefisien korelasi (Uji R) dan Koefisien Determinasi $\left(R^{2}\right)$}

Tabel 4.6 Uji Koefisien Korelasi

Model Summary

\begin{tabular}{|l|c|r|r|r|}
\hline Model & $\mathrm{R}$ & R Square & $\begin{array}{c}\text { Adjusted R } \\
\text { Square }\end{array}$ & $\begin{array}{r}\text { Std. Error of } \\
\text { the Estimate }\end{array}$ \\
\hline 1 & $.689^{\mathrm{a}}$ & .474 & .450 & 1.31961 \\
\hline
\end{tabular}

a. Predictors: (Constant), Disiplin Kerja (X2),

Lingkungan Kerja

Berdasarkan tabel di atas dapat diketahui baha nilai korelasi (R) yang dihasilkan adalah sebesar 0,689. Maka dapat disimpulkan bahwa terdapat hubungan yang cukup berarti antara variabel independen terhadap variabel dependen.

Sedangkan nilai R Square sebesar 0,474. Hal ini menunjukkan bahwa Lingkungan Kerja dan Disiplin Kerja secara keseluruhan memberikan pengaruh 
sebesar 47,4\% terhadap Kinerja, Sedangkan sisanya sebesar 52,6\% dipengaruhi oleh variabel lain yang tidak diteliti dalam penelitian ini.

\section{KESIMPULAN}

Berdasarkan hasil penelitian yang dilandasi dengan kajian teori dan perumusan masalah yang telah dibahas, selanjutnya dapat diambil kesimpulan sebagai berikut:

1. Pengaruh lingkungan kerja terhadap pegawai Dinas Perindustrian dan Perdagangan Kabupaten Indragiri Hilir menunjukkan thitung $(4,682)$ $>$ ttabel $(2,016)$ dengan nilai signifikasi yang dihasilkan 0,000 masih berada dibawah 0,05. Hal ini menunjukkan bahwa lingkungan kerja secara parsial memiliki pengaruh positif dan signifikan terhadap kinerja Aparatur Sipil Negara pada Dinas Perindustrian dan Perdagangan Kabupaten Indragiri Hilir

2. Pengaruh disiplin kerja terhadap kinerja Aparatur Sipil Negara pada Dinas Perindustrian dan Perdagangan Kabupaten Indragiri Hilir menunjukkan thitung $(2,035)>$ ttabel $(2,016)$ dengan nilai signifikasi yang dihasilkan 0,048 berada diatas 0,05 . Hal ini menunjukkan bahwa disiplin kerja secara parsial memiliki pengaruh yang positif dan signifikan terhadap kinerja pada Aparatur Sipil Negara pada Dinas Perindustrian dan Perdagangan Kabupaten Indragiri Hilir.

3. Nilai $\mathrm{F}$ hitung $(19,397)>\mathrm{F}$ tabel $(3,21)$ dengan nilai signifikasi $(0,000)>0,05$. Artinya secara simultan atau bersamaan lingkungan kerja dan disiplin kerja memiliki pengaruh yang signifikan terhadap kinerja Aparatur Sipil Negara pada Dinas Perindustrian dan Perdagangan Kabupaten Indragiri Hilir.

4. Nilai R Square sebesar 0,474 berarti persentase sumbangan pengaruh Lingkungan Kerja dan Disiplin Kerja terhadap Kinerja Aparatur Sipil Negara pada Dinas Perindustrian dan Perdagangan Kabupaten Indragiri Hilir sebesar 47,4\% dan sisanya sebesar 52,6\% dijelaskan 
oleh variabel lain yang tidak dimasukkan atau tidak dibahas pada penelitian ini.

5. Berdasarkan pengamatan peneliti, Lingkungan kerja dan disiplin kerja memiliki kontribusi yang cukup besar terhadap kinerja, tetapi masih ada beberapa faktor atau variabel lain yang dapat mempengaruhi kinerja pada Aparatur Sipil Negara pada Dinas Perindustrian dan Perdagangan Kabupaten Indragiri Hilir.

\section{DAFTAR PUSTAKA}

Hasibuan, Malayu. 2012. Manajemen Sumber Daya Manusia Edisi Revisi.

PT Bumi Aksara, Jakarta.

Mangkunegara, Anwar Prabu. 2008. Manajemen Sumber Daya Manusia. PT Remaja Rosdakarya, Bandung.

Mulyadi. 2015. Manajemen Sumber Daya Manusia (MSDM).

In media, Bogor.

Nitisemito, Alex. 2010. Manajemen Personalia. Edisi Ketiga. Ghalia Indonesia.

Jakarta.

Nurmansyah, 2011. Manajemen Sumber Daya Manusia Suatu Pengantar, Unilak Press, Pekanbaru.

Rivai, Veithzal. 2010. Manajemen Sumber Daya Manusia Untuk Perusahaan,

Raja Wali Pers, Jakarta.

Sedarmayanti, 2009. Sumber Daya Manusia dan Produktifitas Kerja. Ilham Jaya, Bandung.

Sugiyono, 2009. Metode Penelitian Kualitatif, Kuantitatif dan $R \& D$, Alfabeta, Bandung.

Wibowo, 2011. Manajemen Kinerja, PT Raja Grafindo. Jakarta. 